\title{
Karol Kukuła*
}

Uniwersytet Rolniczy im. Hugona Kołłątaja w Krakowie

\section{DYNAMIKA POZYSKIWANIA ENERGII ODNAWIALNEJ W POLSCE W LATACH 2010-2014}

\begin{abstract}
Streszczenie
Celem artykułu jest analiza dynamiki wybranych nośników energii odnawialnej w latach 2010-2014. W toku realizacji tego celu przedstawiono zmiany struktury omawianych nośników, wskazując kierunki jej zmian. Z uwagi na to, że pozyskiwanie energii odnawialnej traktuje się obecnie jako jeden z ważnych czynników proekologicznych, porównano ze sobą dwa rankingi krajów należących do pierwszej dziesiątki w Unii Europejskiej ze względu na: emisję gazów cieplarnianych oraz pozyskiwanie energii odnawialnej. Porównanie zrealizowano w 2014 roku, zaś odnotowane w obu rankingach pozycje dotyczące Polski należy ocenić jako niekorzystne. Kolejnym etapem jest szacowanie liniowych trendów opisujących zmiany nośników energii odnawialnej. Otrzymane wyniki estymacji modeli tendencji rozwojowej pozwalają porównywać średnioroczne przyrosty nośników energii. Dla uzupełnienia porównań dynamiki kształtowania się poszczególnych nośników zaproponowano miarę $k$. Miara ta eliminuje skalę (rząd wielkości) badanego zjawiska. W obu porównaniach dynamiki najlepiej wypada energia wiatrowa. Zwrócono uwagę na nośniki spełniające dotychczas marginalną rolę w ich strukturze. Są to: odpady komunalne, pompy ciepła, energia słoneczna i biogaz rolniczy. Nośniki te mogą w przyszłości odegrać bardziej znaczącą rolę niż obecnie.
\end{abstract}

Słowa kluczowe: dynamika, energia odnawialna, model, trend, energia wiatrowa

\footnotetext{
*Adres e-mail: ksm@ur.krakow.pl.
} 


\section{Wprowadzenie}

Odnawialne źródła energii to takie źródła, których eksploatacja nie jest związana z chwilowym bądź długotrwałym ich brakiem, ponieważ ich zasoby są uzupełniane bez ograniczeń w czasie. Odnawialne źródła energii, takie jak: słońce, wiatr czy woda, są dostępne za darmo. Mimo tej dostępności do końca XX wieku ich wykorzystanie generowało wyższe koszty w porównaniu z eksploatacją klasycznych źródeł, to jest węgla kamiennego, węgla brunatnego czy ropy. Postęp w zakresie technologii związanych z pozyskiwaniem energii odnawialnej spowodował zwiększenie skali jej wykorzystania i wpłynął znacząco na obniżenie kosztów. Należy w tym miejscu podkreślić bezinwazyjny charakter procesów pozyskiwania energii odnawialnej w stosunku do środowiska, co istotnie wzmacnia argumenty przemawiające za ich kontynuacją i wzrostem udziału w ogólnym bilansie produkcji energii. Energetykę konwencjonalną charakteryzuje duża zmienność cen na rynku paliw kopalnych, a także narastające koszty związane z emisją $\mathrm{CO}_{2}$. Wszystko to skutkuje stale rosnącymi cenami energii elektrycznej. Warto dodać, iż pośród wszystkich nośników odnawialnych źródeł energii (OZE) najniższe nakłady na budowę nowych instalacji charakteryzują energetykę wiatrową.

$\mathrm{Z}$ uwagi na liczne argumenty przemawiające za pełniejszym wykorzystywaniem nośników energii odnawialnej oraz na tendencje obserwowane w tym zakresie w Japonii, Chinach, Stanach Zjednoczonych, a także w krajach Unii Europejskiej, również w Polsce muszą nastąpić zmiany związane z powolnym odchodzeniem od energetyki konwencjonalnej, opartej w głównej mierze na węglu, do energetyki wykorzystującej OZE. Konstatacja ta pozwala wyróżnić wybrane problemy prowadzonych badań w zakresie pozyskiwania energii odnawialnej w Polsce.

Głównym celem artykułu jest analiza dynamiki pozyskiwania poszczególnych nośników energii odnawialnej w naszym kraju w latach 2010-2014. Kolejnym celem jest dokonanie porównań w średniorocznych przyrostach względnie spadkach badanych nośników. Do realizacji tego celu wykorzystano modele tendencji rozwojowej. Ponadto zwrócono uwagę na zmiany strukturalne zachodzące w rozpatrywanym zjawisku.

Statystyczna analiza porównawcza spełnia ważne zadania we współczesnych badaniach poświęconych gospodarce. Obok wielokryterialnych porównań między obiektami równie istotną rolę do odegrania mają porównawcze badania dynamiki 
rozwoju zjawisk społeczno-ekonomicznych. W naszych badaniach interesujące poznawczo są porównania w zakresie dynamiki kształtowania się poszczególnych nośników energii odnawialnej w Polsce oraz ocena ich udziału w pozyskiwaniu tejże energii. Jako narzędzie badawcze pozwalające śledzić zmiany nośników OZE, zachodzące w czasie, wykorzystywano modele tendencji rozwojowej.

\section{Pozyskiwanie energii odnawialnej a emisja gazów cieplarnianych w Polsce na tle wybranych państw Unii Europejskiej}

Pozyskiwanie energii odnawialnej znajduje bezpośrednie przełożenie na zaspokajanie wciąż rosnącego zapotrzebowania na energię elektryczną w kraju (zob. Kukuła, 2015a). Chodzi mianowicie o produkcję energii elektrycznej z wykorzystaniem tak zwanych technologii czystych, to jest niezanieczyszczających środowiska, w tym również atmosfery. Polska jest bowiem znaczącym w skali europejskiej emitentem gazów cieplarnianych, zajmując piątą lokatę w tym niechlubnym rankingu pośród państw Unii Europejskiej (zob. tab. 1). Wyprzedzają nas tylko Niemcy, Wielka Brytania, Francja i Włochy (por. Kukuła, 2015b).

Jeśli wziąć pod uwagę zobowiązania, jakie ostatnio przyjęła Polska w zakresie ograniczeń emisji gazów cieplarnianych, to można stwierdzić, iż wiele pozostaje do zrobienia na tym odcinku. W tym miejscu łatwo wskazać, iż musimy stopniowo ograniczać tradycyjną energetykę opartą na węglu na rzecz szerszego wykorzystywania OZE. Proces ten jednak musi mieć przebieg o charakterze ewolucyjnym.

Nieco odmiennie kształtuje się kolejność w rankingu pierwszej dziesiątki państw Unii Europejskiej ze względu na wielkość pozyskiwanej energii odnawialnej (zob. tab. 2). Tu wyprzedzają nas zdecydowanie Niemcy, Francja, Szwecja, Włochy, Hiszpania, Finlandia, a nawet tak niewielkie państwo jak Austria. Ósma lokata Polski w tym rankingu to znacznie niższa pozycja od tej, jaką Polska zajmuje na liście emitentów gazów cieplarnianych. Stan ten poniekąd przeczy zasadzie: więcej emitujesz, zanieczyszczając atmosferę, więcej pozyskujesz energii odnawialnej. Zasadzie tej hołdują czołowe kraje Unii Europejskiej, takie jak: Niemcy, Francja, Włochy i Hiszpania, których pozycje w obu rankingach są niemal identyczne (por. tab. 1 i 2 ). 
Tabela 1. Czołowa dziesiątka państw

- emitentów gazów cieplarnianych w Europie w 2012 roku (według ekwiwalentu $\mathrm{CO}_{2}$ )

\begin{tabular}{|c|l|c|}
\hline Lokata & \multicolumn{1}{|c|}{ Kraje } & $\begin{array}{c}\text { Wielkość } \\
\text { produkcji energii } \\
\text { odnawialnej } \\
\text { w tys. toe }\end{array}$ \\
\hline 1. & Niemcy & 32912,7 \\
\hline 2. & Francja & 20766,0 \\
\hline 3. & Szwecja & 18509,9 \\
\hline 4. & Włochy & 18056,0 \\
\hline 5. & Hiszpania & 14487,4 \\
\hline 6. & Finlandia & 9930,7 \\
\hline 7. & Austria & 9623,2 \\
\hline $\mathbf{8 .}$ & Polska & $\mathbf{8 4 7 8 , 0}$ \\
\hline 9. & Wielka & 7095,0 \\
\hline 10. & Rrytania & 5242,2 \\
\hline
\end{tabular}

\begin{tabular}{|c|l|c|}
\hline Lokata & Kraje & $\begin{array}{c}\text { Wielkość } \\
\text { emisji gazów } \\
\text { cieplarnianych } \\
\text { ogółem w mln ton }\end{array}$ \\
\hline 1. & Niemcy & 964,6 \\
\hline 2. & $\begin{array}{l}\text { Wielka } \\
\text { Brytania }\end{array}$ & 613,1 \\
\hline 3. & Francja & 506,4 \\
\hline 4. & Włochy & 495,5 \\
\hline 5. & Polska & 400,9 \\
\hline 6. & Hiszpania & 354,4 \\
\hline 7. & Holandia & 201,8 \\
\hline 8. & Czechy & 132,4 \\
\hline 9. & Belgia & 120,6 \\
\hline 10. & Rumunia & 119,2 \\
\hline
\end{tabular}

Źródło: opracowanie własne na podstawie danych zawartych w: GUS (2014), s. 512, 506.

\section{Zmiany w strukturze nośników energii odnawialnej}

Struktura źródeł pozyskiwania energii odnawialnej w Polsce ulega systematycznym zmianom (zob. tab. 3). Nawet w tak stosunkowo krótkim okresie (2010 2014) poszczególne składowe tej struktury ewoluują, przyjmując stałą orientację. I tak największy element struktury - biopaliwa stałe - systematycznie zmniejsza swój udział w strukturze nośników energii odnawialnej z około 85,5\% w 2010 roku do 76,6\% w 2014 roku. Spada również udział energii wody odpowiednio z 3,66\% w okresie wyjściowym do 2,33\% w ostatnim obserwowanym okresie. Frakcje pozostałych nośników energii odnawialnej wykazują tendencję wzrostową z różnym natężeniem. Najszybsze wzrosty udziałów odnotowano w przypadku takich nośników, jak: odpady komunalne (z 0,04\% w 2010 r. do 0,46\% w 2014 r.) oraz energia wiatrowa (z 2,09 do 8,18\% w porównywanych okresach). Należy 
nadmienić, iż poszczególne udziały nośników energii odnawialnej zostały zapisane w tabeli 3 według ich wielkości w 2014 roku. Tak więc pięć pierwszych pozycji zajmują w kolejności: biopaliwa stałe i ciekłe, energia wiatru, biogaz i energia wód, dostarczając łącznie prawie 99\% energii odnawialnej. Pozostałe cztery nośniki mają w tej strukturze marginalne znaczenie, dając łącznie niewiele ponad 1\% energii odnawialnej.

Tabela 3. Struktura źródeł pozyskiwania energii odnawialnej w Polsce w latach 2010-2014

\begin{tabular}{|c|l|r|r|r|r|r|}
\hline \multirow{2}{*}{ Lp. } & \multirow{2}{*}{ Wyszczególnienie } & 2010 & 2011 & 2012 & 2013 & 2014 \\
\cline { 3 - 7 } & & \multicolumn{5}{|c|}{$\%$} \\
\hline 1. & Biopaliwa stałe & 85,48 & 85,18 & 82,35 & 80,25 & 76,62 \\
\hline 2. & Biopaliwa ciekłe & 6,66 & 5,78 & 7,99 & 8,22 & 9,23 \\
\hline 3. & Energia wiatru & 2,09 & 3,70 & 4,81 & 6,06 & 8,18 \\
\hline 4. & Biogaz & 1,67 & 1,84 & 1,98 & 2,13 & 2,57 \\
\hline 5. & Energia wody & 3,66 & 2,69 & 2,16 & 2,46 & 2,33 \\
\hline 6. & Odpady komunalne & 0,04 & 0,43 & 0,38 & 0,39 & 0,46 \\
\hline 7. & Energia geotermalna & 0,20 & 0,17 & 0,19 & 0,22 & 0,25 \\
\hline 8. & Energia słoneczna & 0,12 & 0,14 & 0,15 & 0,18 & 0,21 \\
\hline 9. & Pompy ciepła & 0,09 & 0,09 & 0,09 & 0,10 & 0,15 \\
\hline
\end{tabular}

Źródło: GUS (2015). s. 30.

Warto podkreślić silną dynamikę zmian trzeciego co do wielkości frakcji nośnika energii odnawialnej - energii wiatrowej. Jej udział wzrósł prawie czterokrotnie w badanym okresie. Stosunkowo silne zmiany udziału odnotowano również w pozyskiwaniu energii słonecznej - niecały dwukrotny jego wzrost w rozpatrywanym okresie. Wszystko to wskazuje na powolne ale dostrzegalne pozytywne przemiany w tzw. „energetyce czystej”. 


\section{Modele tendencji rozwojowej wybranych nośników energii odna- wialnej}

Celem analizy przeobrażeń w czasie wybranych nośników energii odnawialnej zastosowano narzędzie ekonometryczne zwane modelem tendencji rozwojowej. Modele tendencji rozwojowej zawierają trzy składowe: trend, wahania okresowe oraz wahania losowe (składnik losowy). W naszym badaniu poprzestano na trendzie i składniku losowym wobec braku symptomów okresowości. W opisie dynamiki wszystkich nośników wykorzystano postać trendu liniowego o postaci:

$$
Y_{t}=\alpha_{0}+\alpha_{1} t+\varepsilon_{t},
$$

gdzie:

$Y_{t}$ - zmienna objaśniana (nośnik energii),

$t$ - zmienna czasowa $(\mathrm{t}=1, \ldots, 5)$,

$\alpha_{0}, \alpha_{1}-$ parametry strukt uralne modelu,

$\varepsilon_{t}$ - składnik losowy.

W jednym tylko przypadku oszacowano dodatkowo trend paraboliczny o postaci:

$$
Y_{t}=\alpha_{0}+\alpha_{1} t+\alpha_{2} t^{2}+\varepsilon_{t}
$$

gdzie $\alpha_{0}, \alpha_{1}$ i $\alpha_{2}$ to parametry strukturalne modelu. Do estymacji modeli wykorzystano dane o wielkościach nośników energii odnawialnej z lat 2010-2014. Informacje te zawiera tabela 4 .

\begin{tabular}{|c|c|c|c|c|c|c|}
\hline \multirow{2}{*}{$\mathrm{Lp}$} & \multirow{2}{*}{$\begin{array}{l}\text { Źródła pozyskania } \\
\text { energii odnawialnej }\end{array}$} & \multicolumn{5}{|c|}{ LATA } \\
\hline & & 2010 & 2011 & 2012 & 2013 & 2014 \\
\hline 1 & Biopaliwa stałe & 245606 & 265888 & 292562 & 286243 & 258723 \\
\hline 2 & Biopaliwa ciekłe & 19123 & 18030 & 28371 & 29315 & 31156 \\
\hline $2 \mathrm{a}$ & Biodiesel & 14584 & 13974 & 23247 & 24217 & 27343 \\
\hline 3 & Energia wiatru & 5992 & 11536 & 17088 & 21614 & 27632 \\
\hline 4 & Biogaz & 4797 & 5731 & 7032 & 7593 & 8671 \\
\hline $4 \mathrm{a}$ & Biogaz z oczyszczalni ścieków & 2652 & 2775 & 3321 & 3572 & 3810 \\
\hline 5 & Energia wody & 10512 & 8393 & 7333 & 8781 & 7857 \\
\hline 6 & Odpady komunalne & 123 & 1338 & 1360 & 1391 & 1544 \\
\hline 7 & Energia geometralna & 563 & 531 & 661 & 778 & 847 \\
\hline 8 & Energia słoneczna & 350 & 434 & 544 & 639 & 720 \\
\hline 9 & Pompy ciepła & 248 & 266 & 308 & 339 & 509 \\
\hline
\end{tabular}

Tabela 4. Pozyskiwanie energii odnawialnej wg nośników w latach 2010-2014 [w TJ] 
Wyniki szacowania modeli, to jest estymatory parametrów strukturalnych oraz parametrów struktury stochastycznej $\left[S^{2}(u), V(u), R^{2}\right.$ oraz błędy średnie szacunku parametrów], zawiera tabela 5. Otrzymane wyniki charakteryzują wartości parametrów struktury stochastycznej $\left(S^{2}(u), V(u), R^{2}\right.$ oraz błędy średnie szacunku parametrów). Na ogół we wszystkich przypadkach ich wartości były zadawalające (zob. tab. 5). Wyjątek stanowią trendy liniowe biopaliw stałych oraz energii wody. W przypadku biopaliw stałych dokonano zmiany postaci analitycznej, szacując model paraboliczny, którego parametry struktury stochastycznej można uznać za zadowalające. W przypadku energii wody przyjęto opcję pozostania przy dotychczasowej postaci. Ma to umożliwić przeprowadzenie procedury porównawczej w zakresie kształtowania się dynamiki poszczególnych nośników energii odnawialnej. Wiadomo, że w trendach liniowych parametr $\left(\alpha_{1}\right)$ (stojący przy zmiennej czasowej $t$ określa średnioroczny przyrost, względnie przy ujemnym znaku średnioroczny spadek badanego zjawiska. Wiadomo również, że parametry te można porównać, lecz wykazują one bardzo zróżnicowane wartości. Przy nośnikach, których udziały są wysokie, na przykład w przypadku biopaliw stałych, ten parametr wynosi 4658,9 TJ (średnioroczny przyrost wyrażony w teradżulach), w przypadku nośnika energii słonecznej ten przyrost kształtuje się na poziomie niecałych 95 TJ.

Powstaje pytanie: Jak pokazać względną dynamikę zmian, aby wyeliminować rząd wielkości poszczególnych nośników energii? Proponuje się zastosować miarę o postaci:

gdzie:

$$
k_{i}=\frac{a_{1 i}}{\bar{y}_{i}},(i=1, \ldots, 9), \quad \bar{y}_{i} \neq 0,
$$

$i$ - numer kolejny nośnika energii odnawialnej,

$a_{1 i}$ - parametr określający średnioroczny przyrost $i$-tego nośnika energii odnawialnej,

$\bar{y}_{i}-$ średnia wartość $i$-tego nośnika energii odnawialnej,

$k_{i}$ - zrelatywizowana wartość miary średniorocznych przyrostów $i$-tego nośnika energii odnawialnej.

W przypadku, gdy mamy do czynienia z dodatnimi średniorocznymi przyrostami zmiennej $y_{i t}\left(\alpha_{i 1}>0\right)$, wówczas miara $k_{\mathrm{i}}$ może przyjmować wartości z przedziału $0<k_{i}<1$. Gdy zaś obserwuje się ujemne przyrosty $\left(\alpha_{i 1}<0\right)$ zmiennej $y_{i t}$, wówczas $k_{i}$ przyjmuje wartości z przedziału $-1<k_{i}<0$. Wartości $k_{i}$ oddalające się 
coraz bardziej od zera wskazują na coraz silniejszą dynamikę zmian $i$-tej zmiennej (tu nośnika energii odnawialnej).

Przeciętne roczne przyrosty poszczególnych nośników energii odnawialnej oraz ich relatywizacje są zamieszczone w tabeli 6 . Łatwo zauważyć, że największe przyrosty odnotowano w czterech nośnikach energii: energia wiatrowa (5335 TJ), biopaliwa stałe (4658 TJ), biodiesel (3576,1 TJ) i biopaliwa ciekłe (3535,1 TJ).

Tabela 5. Trendy wybranych nośników źródeł energii odnawialnej [TJ]

\begin{tabular}{|c|c|c|c|c|c|c|}
\hline \multirow{2}{*}{ Lp. } & \multirow{2}{*}{\multicolumn{2}{|c|}{$\begin{array}{l}\text { Źródła pozyskania energii } \\
\text { odnawialnej }\end{array}$}} & \multirow{3}{*}{$\begin{array}{c}\text { Trend } \\
(\mathrm{t}=1,2,3,4,5) \\
=\begin{array}{l}255827,7+46589 t \\
(21789,1) \quad(6569,6)\end{array}\end{array}$} & \multicolumn{3}{|c|}{$\begin{array}{l}\text { Parametry struktury } \\
\text { stochastycznej }\end{array}$} \\
\hline & & & & $S_{u}^{2}$ & $\mathrm{~V}_{u}$ & $\mathrm{R}^{2}$ \\
\hline \multirow{2}{*}{1.} & \multirow{2}{*}{$\begin{array}{l}\text { Biopaliwa } \\
\text { stałe }\end{array}$} & trend liniowy & & 20775,056 & 0,077 & 0,144 \\
\hline & & $\begin{array}{l}\text { trend } \\
\text { paraboliczny }\end{array}$ & $\hat{y}_{1 t}=\underset{(52514)}{288175,4}+\underset{(2387,5)}{4661,5 t}-\underset{(20118)}{9185,5 t^{2}}$ & 56776468,6 & 0,075 & 0,925 \\
\hline 2. & \multicolumn{2}{|c|}{ Biopaliwa ciekłe } & $\hat{y}_{2 t}=\underset{(3077,6)}{14593,7}+\underset{(927,9)}{3535,1 t}$ & 2934,388 & 0,116 & 0,829 \\
\hline $2 \mathrm{a}$. & \multicolumn{2}{|l|}{ Biodiesel } & $\hat{y}_{2 a t}=\underset{(2550,6)}{9944,7}+\underset{(769,0)}{3576,1 t}$ & 2431,866 & 0,118 & 0,878 \\
\hline 3. & \multicolumn{2}{|c|}{ Energia wiatru } & $\hat{y}_{3 t}=\underset{(383,4)}{765,0+} \underset{(115,6)}{5335,8 t}$ & 365,558 & 0,022 & 0,999 \\
\hline 4. & \multicolumn{2}{|l|}{ Biogaz } & $\hat{y}_{4 t}=\underset{(188,3)}{3881,8}+\underset{(56,8)}{961,0 t}$ & 179,517 & 0,027 & 0,990 \\
\hline $4 \mathrm{a}$. & \multicolumn{2}{|c|}{$\begin{array}{l}\text { Biogaz z oczyszczalni } \\
\text { ścieków }\end{array}$} & $\hat{y}_{4 a t}=\underset{(111,0)}{2292,1+\underset{(33,5)}{311,3 t}}$ & 115,000 & 0,033 & 0,966 \\
\hline 5. & \multicolumn{2}{|c|}{ Energia wody } & 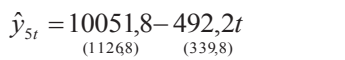 & 1074,400 & 0,125 & 0,412 \\
\hline 6. & \multicolumn{2}{|c|}{ Odpady komunalne } & $\hat{y}_{6 t}=\underset{(432,2)}{282,7}+\underset{(130,3)}{289,5 t}$ & 412,060 & 0,358 & 0,622 \\
\hline 7. & \multicolumn{2}{|c|}{ Energia geotermalna } & $\hat{y}_{7 t}=\underset{(51,5)}{431,5}+\underset{(15,5)}{81,5 t}$ & 49,131 & 0,073 & 0,902 \\
\hline 8. & \multicolumn{2}{|c|}{ Energia słoneczna } & $\hat{y}_{8 t}=\underset{(8,9)}{253,9+\underset{(2,7)}{94,5 t}}$ & 8,499 & 0,016 & 0,998 \\
\hline 9. & \multicolumn{2}{|c|}{ Pompy ciepła } & $\hat{y}_{9 t}=\underset{(54,0)}{155,5}+\underset{(16,3)}{59,5 t}$ & 51,457 & 0,154 & 0,817 \\
\hline
\end{tabular}

Źródło: opracowanie własne na podstawie danych zawartych w tabeli 4. 
Tabela 6. Średnioroczne przyrosty nośników energii odnawialnej $\left(a_{1 i}\right)$ oraz ich relatywizacje $\left(k_{i}\right)$

\begin{tabular}{|c|c|c|c|c|c|}
\hline \multirow{2}{*}{ Lokata } & \multirow{2}{*}{ Wyszczególnienie } & $a_{1 i}$ & \multirow{2}{*}{ Lokata } & \multirow{2}{*}{ Wyszczególnienie } & \multirow{2}{*}{$k_{i}$} \\
\hline & & $\mathrm{TJ}$ & & & \\
\hline 1. & Energia wiatrowa & 5335,8 & 1. & Energia wiatrowa & 0,318 \\
\hline 2. & Biopaliwa stałe & 4658,9 & 2. & Odpady komunalne & 0,251 \\
\hline 3. & Biodiesel & 3576,1 & 3. & Pompy ciepła & 0,178 \\
\hline 4. & Biopaliwa ciekłe & 3535,1 & 4. & Energia słoneczna & 0,176 \\
\hline 5. & Biogaz & 961,0 & 5. & Biodiesel & 0,173 \\
\hline 6. & $\begin{array}{l}\text { Biogaz z oczyszczalni } \\
\text { ścieków }\end{array}$ & 311,3 & 6. & Biogaz & 0,142 \\
\hline 7. & Odpady komunalne & 289,5 & 7. & Biopaliwa ciekłe & 0,140 \\
\hline 8. & Energia słoneczna & 94,5 & 8. & Energia geotermalna & 0,121 \\
\hline 9. & Energia geotermalna & 81,5 & 9. & $\begin{array}{l}\text { Biogaz z oczyszczalni } \\
\text { ścieków }\end{array}$ & 0,097 \\
\hline 10. & Pompy ciepła & 59,5 & 10. & Biopaliwa stałe & 0,017 \\
\hline 11. & Energia wody & $-492,2$ & 11. & Energia wody & $-0,057$ \\
\hline
\end{tabular}

Źródło: opracowanie własne na podstawie danych zawartych w tabeli 5.

Przyrosty ujemne, czyli średnioroczne spadki, przypisać należy energii wodnej (-492,2 TJ). Przyrosty poniżej 100 TJ rocznie charakteryzują trzy nośniki energii odnawialnej: energię słoneczną, energię geotermalną i pompy ciepła. Celem opisania dynamiki kształtowania się badanych nośników energii nie wystarczy porównywać ich bezpośrednie przyrosty. Ich przeciętne wartości przyrostów pozyskiwania są tu bardzo różne. Przykładowo średnia pozyskiwania energii odnawialnej z biomasy wynosi około $270000 \mathrm{TJ}$, energii wiatrowej około $17000 \mathrm{TJ}$ w stosunku do przeciętnej pozyskiwania energii z pomp ciepła $334 \mathrm{TJ}$ w skali rocznej. Stąd zrodziła się myśl, by zaproponować stosowanie do porównań dynamiki kształtowania się różnych zjawisk współczynnika $k_{i}$. Stanowi on iloraz, w którym średnioroczny przyrost energii (zob. tab. 5) jest odnoszony do przecięt- 
nej wartości rocznej jego pozyskiwania. W ten sposób gubi się efekt skali zjawiska oraz jednostkę jego pomiaru (tu TJ).

Najwyższą dynamikę wzrostu należy przypisać energii wiatrowej, dla której wartość proponowanej miary $(k)$ osiąga poziom 0,318 . Energia wiatrowa przoduje również w rankingu średniorocznych przyrostów energii odnawialnej (tab. 6). $\mathrm{Na}$ wysokiej drugiej pozycji plasuje się energia powstała $\mathrm{z}$ odpadów $\left(\mathrm{k}_{2}=0,251\right)$. Co ciekawe, odpady komunalne zajmują dopiero siódmą lokatę, jeśli brać pod uwagę średnioroczne przyrosty, dając niecałe $0,5 \%$ energii w ogólnym bilansie energii odnawialnej. Drugi zaskakujący przypadek odnotowano w stosunku do biopaliw stałych. Udział ich pozyskiwania w stosunku do pozostałych nośników energii jest najwyższy, chociaż wykazując tendencję spadkową, generuje około $77 \%$ ogółu pozyskanej energii odnawialnej w 2014 roku (zob. tab. 3). Niemniej jednak jeśli wziąć pod uwagę wartość miernika $k_{10}$, to należy podkreślić bardzo niski poziom dynamiki wzrostowej rozmiarów tego nośnika $(0,017)$. Tylko jeden nośnik energii odnawialnej wykazuje tendencję spadkową. Ów słaby trend spadkowy dotyczy energii wody, której średnioroczne spadki kształtują się na poziomie 492 TJ, zaś miernik $k$ wynosi $-0,057$ (zob. tab. 6).

\section{Podsumowanie}

Zrealizowane badania skłaniają do wyrażenia kilku uwag ogólnej natury.

1. W strukturze źródeł pozyskiwanie energii odnawialnej w Polsce wszystkie udziały jej nośników wykazują tendencję wzrostową poza dwoma: energią z biopaliw stałych oraz energią wody.

2. Porównując rankingi pierwszej dziesiątki państw Unii Europejskiej ze względu na emisję gazów cieplarnianych oraz pozyskiwania energii odnawialnej, można zauważyć istotne różnice. Między innymi Polska zajmuje piątą lokatę w Unii pod względem emisji gazów cieplarnianych i zaledwie ósme miejsce na liście europejskich producentów energii odnawialnej.

3. Nadal biopaliwa stałe są największym dostarczycielem energii odnawialnej w Polsce, jednak ich dynamika wzrostowa jest bardzo słaba [dopiero dziesiąte miejsce ze względu na wartości zrelatywizowanych średniorocznych przyrostów $\left.\left(k_{10}=0,017\right)\right]$. 
4. Najwyższą dynamikę wzrostu wśród wszystkich nośników energii odnawialnej przejawia energia wiatrowa. Jej średnioroczne przyrosty wynoszą ponad $5300 \mathrm{TJ}$, zaś zrelatywizowany średnioroczny przyrost osiąga poziom około 0,32 (zob. tab. 6).

5. Stosunkowo wysoką dynamikę wzrostu wykazują dwa marginalne co do wielkości dostarczanej energii nośniki: pompy ciepła i energia słoneczna. Zajmują one odpowiednio trzecie i czwarte miejsce w rankingu ze względu na zrelatywizowane średnioroczne przyrosty.

6. Ujemne przyrosty odnotowano w stosunku do nośnika energia wody. Jego średnioroczne spadki (ponad $492 \mathrm{TJ}$ ) są efektem zaniechań inwestycyjnych w tej dziedzinie. Zaniechania te dotyczą również przyszłości.

7. W ramach ewolucyjnych zmian polskiej energetyki należy podjąć wszelkie wysiłki w kierunku rozwoju takich obecnie marginalnych co do rozmiaru nośników, jak: biogaz z oczyszczalni ścieków, odpady komunalne, pompy ciepła, energia słoneczna oraz biogaz rolniczy. Biogazownie rolnicze będące instalacjami zlokalizowanymi w pobliżu budynków inwentarskich pełnią jednocześnie funkcje utylizacyjne produktów ubocznych gospodarstw rolnych. Tym samym sprzyjają ich wykorzystaniu oraz oddziałują proekologicznie na środowisko (por. Gostomczyk, 2015; Powałka, Klepacka, Skudlarski, Golisz, 2013).

8. Należy nadal utrzymywać wysoką dynamikę wzrostową pozyskiwania energii wiatrowej, w którą jak dotąd dużo zainwestowano i w którą nadal należy inwestować. Chodzi tu w głównej mierze o wspieranie budowy małych elektrowni wiatrowych na poziomie gmin, a nawet prywatnych gospodarstw rolnych. Wiele do zrobienia mają $\mathrm{w}$ tej mierze inicjatywy legislacyjne sprzyjające tym małym przedsięwzięciom. Obok tworzenia małych elektrowni wiatrowych istnieją możliwości budowy morskich elektrowni wiatrowych o wysokiej efektywności, ale i o wysokich kosztach instalacji.

\section{Literatura}

Gostomczyk, W. (2015). Rynek biogazu rolniczego w Polsce i wykorzystywane surowce w latach 2011-2014. Problemy Rolnictwa Światowego, 15 (3), 30-39.

GUS (2014). Ochrona środowiska - Environment 2014. Warszawa.

GUS (2015). Energia ze źródet odnawialnych w 2014 r. Warszawa. 
Kukuła, K. (2015a). Dynamika produkcji energii elektrycznej wykorzystującej źródła energii odnawialnej. Wiadomości Statystyczne, 12, 58-69.

Kukuła, K. (2015b). Struktura oraz dynamika produkcji energii odnawialnej w państwach UE. Europa Regionum, XXIII, 173-184.

Powałka, M., Klepacka, A.M., Skudlarski, J., Golisz, E. (2013). Aktualny stan biogazu rolniczego w Polsce na tle krajów Unii Europejskiej. Problemy Rolnictwa Światowego, 13 (3), 203-212.

\title{
DYNAMICS OF ACQUIRING OF RENEWABLE ENERGY IN POLAND OVER THE PERIOD OF 2010-2014
}

\begin{abstract}
The paper presents the analysis of the dynamics of chosen renewable energy carriers over the period of 2010-2014. In particular, changes of the structure of the carriers under discussion was shown and the direction of these changes was determined. Regarding the fact that the problem of acquiring renewable energy is treated as one of important pro ecological factors two ranking arrangements of the first ten EU countries were compared with respect to: greenhouse gas emission and acquiring renewable energy. The comparison concerns the year 2014. The position of Poland in each of the two ranking arrangement can be estimated as unfavourable. In further analysis linear trends describing changes of renewable energy carriers were estimated. The results of the estimation of the models allow for the comparison of yearly average increases of renewable energy carriers. In order to obtain full picture of the dynamics comparison results $k$ measure was proposed. This measure eliminates scale (the size degree) of the phenomenon under investigation. In case of both comparisons the best estimation is assigned to the wind energy. In addition, renewable energy carriers of minor significance up to now were concerned, in particular communal waste, heat pump, solar energy and agricultural biogas. These carriers may become more significant in future.
\end{abstract}

Keywords: dynamics, renewable energy, model, trend, wind energy

JEL codes: Q2, Q42 